\title{
Study on Application of the Autoclaved Sand-Lime Brick in Masonry Structure of villages and towns
}

\author{
Yuhang $\mathrm{Hao}^{1, \mathrm{a}^{*}}$,Jiangshan $\mathrm{He}^{2, \mathrm{~b}}$, Hongbin $\mathrm{Lu}^{2, \mathrm{c}}$ \\ ${ }^{1}$ Hebei Building Research Engineering Co., Ltd, Shijiazhuang 050200, China \\ ${ }^{2}$ Hebei honghua Construction Engineering Co., Ltd, Baoding 074299, China \\ ahaoyuhangdayu@126.com, b784544418@qq.com, '491848985@qq.com
}

\section{Keywords: Autoclaved sand-lime brick, Masonry structure, Villages and towns}

\begin{abstract}
In order to solve a series of problems caused by disabled clay brick, studied on the new wall materials which applicable to North China, combined with local resource of Shijiatong village, the autoclaved sand-lime brick was selected as the demonstration area of new wall materials. Summarized autoclaved sand-lime brick in engineering application problems, the methods to improve the performance were put forward by testing, and according to the wall construction characteristics in villages and towns of North China put forward the corresponding key construction technical measures.
\end{abstract}

\section{Introductions}

For years, the wall building materials in North China has been based on clay brick masonry as the main material, starting from 2000, due to solid brick high consumption of resources, serious waste of resources arable land is prohibited by the State. Some cities also issued a notice explicitly, expressly stated ban on the production, operation sintered clay brick, the construction unit shall not be any reason to use clay bricks, and design units in the design cannot select clay brick. In order to replace the traditional solid clay brick wall as the main material, The State Council also approved the National Development and Reform Commission, the State Economic and Trade Commission, the State Planning Commission issued a 《Wall Materials Innovation guidance in "12th Five-year" 》, 《The several suggestions of developing the new advanced constructive materials》 and a series of provisions for industry adjustment of the structure of the building materials, development of high technological content, functional diversification of new building material. In order to solve a series of problems caused by disabled clay brick, studied on the new wall materials which applicable to North China, Summarized autoclaved sand-lime brick in engineering application problems, the methods to improve the performance were put forward by testing, and according to the wall construction characteristics in villages and towns of North China put forward the corresponding key construction technical measures [1].

\section{Localization of New Wall Selection in Shijiatong Demonstration Area}

Shijiatong village under Xishanbeixiang, Yi County, there are three kinds of large reserves of building materials, such as lime, sand, gravel. Local building materials manufacturers can improvise use the local rich mineral resources reasonably to provide the corresponding wall building materials for the construction and development of the local towns, promote the transformation and upgrading of building materials.

Autoclaved sand-lime brick is lime, sand, quartz sand tailings as the main raw material, allowing the incorporation of pigments and additives, by mixing with water, the digestion reaction, billets, pressing autoclave curing made by a kind of bulk material. The main raw material for autoclaved sand-lime brick is sand, the production process without the use of clay; regular size, small 
deformation, less prone to missing edge off angle conditions; a strong regenerative capacity; the use of autoclaved sand-lime brick architecture can effectively reduce the construction costs of the building. Meanwhile autoclaved sand-lime brick can reduce pollution and environmental destruction of arable land, with great economic and social benefits. Therefore, chose the autoclaved sand-lime brick as the new wall materials of Shijiatong demonstration area [2].

\section{Performance Improvement Technology of Autoclaved Sand-Lime Brick}

By studying the mechanical properties of autoclaved lime sand brick we found the following problems [3]:

(1) The same level of compressive strength of autoclaved sand-lime brick and clay is basically the same, but lower than the shear strength of clay brick;

(2) Moisture content has a greater impact on shear strength of autoclaved sand-lime brick, the optimum moisture content of autoclaved sand-lime brick should be determined;

To solve the problems, study on the molding pressure and the optimum moisture content, and establish the improved performance specifications of autoclaved lime sand brick.

Effects of Molding Pressure on the Compressive Strength of Autoclaved Sand-Lime Brick. During the preparation of autoclaved sand-lime brick, compression molding process is the most important process, molding pressure and pressing manner has a key role on the quality of products. Test by studying the effects of molding pressure on the strength of the finished product, determining parameters of hydraulic pressure machine of repression. The lime and sand mixed with water proportionally, and maturing $4.5 \mathrm{~h}$, at different pressures $(15 \mathrm{MPa} \sim 25 \mathrm{MPa})$ formed under static stop $3 \mathrm{~h}$ back into the kettle, the autoclave is heating up $1.5 \mathrm{~h}$, thermostat $5 \mathrm{~h}$, constant temperature was 174.5 degrees, constant pressure is $0.90 \mathrm{MPa}$, the cooling time $1.5 \mathrm{~h}$, piled up out of autoclave. Test results are shown in the following figure.

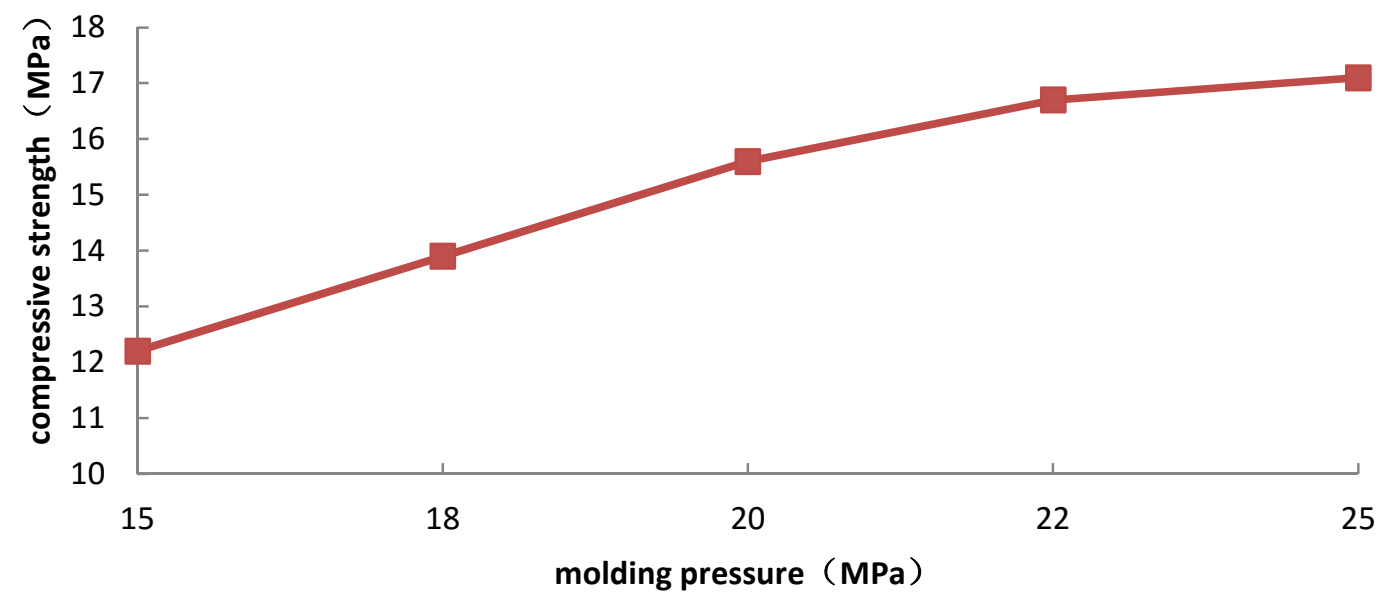

Fig. 1 Relationship between compressive strength of test pieces and molding pressure.

The pressure of the hydraulic press currently used mostly located $28 \mathrm{MPa}$ or less, therefore, this test will limit the scope of the molding pressure between $15 \mathrm{MPa}$ and $25 \mathrm{MPa}$. Tests showed that when the molding pressure was increased within a certain range, the compressive strength of autoclaved sand-lime brick improved significantly. When the molding pressure is less than 22MPa with the compressive strength of autoclaved lime sand brick molding pressure increased with the increase, and the increase by a big margin; when the pressure exceeds $22 \mathrm{MPa}$, the sand-lime brick compressive strength of autoclaved although still with the molding pressure increases increase, but improved to a lesser extent. When the molding pressure from $15 \mathrm{MPa}$ up to $22 \mathrm{MPa}$, the compressive strength of autoclaved lime sand brick improved $4.5 \mathrm{MPa}$, an increase of $36.9 \%$; but the molding 
pressure increases from $22 \mathrm{MPa}$ to $25 \mathrm{MPa}$, strength increased only $0.4 \mathrm{MPa}$, an increase of only $2.4 \%$, the growth trend has leveled off state.

Through the above test can be found, the specimen strength of autoclaved sand-lime brick enhanced with raw material body molding pressure increased, but in the actual production process, with the raw material body molding pressure increased, more difficulty of demolding, the most common problem are body-off corners, edges and internal spall off. These phenomena commonly caused by uneven mixing of raw materials or pressing too fast in the process of rolling. Therefore, should avoid pressing too fast when press the raw body. From the actual production operations, $1 \sim 2 \mathrm{kN} / \mathrm{s}$ meets body shaping requirements.

In summary, more appropriate body swells material forming pressure is about $22 \mathrm{MPa}$ in the present conditions, and pressing speed control in $1 \sim 2 \mathrm{KN} / \mathrm{s}$.

Effect of Moisture Content on Autoclaved Sand Lime Brick Masonry Shear Strength. Since the shear strength of autoclaved sand-lime brick is lower than the ordinary brick, should use good construction technology to improve the shear strength of autoclaved sand-lime brick masonry. in the construction process, the main factor affecting the shear strength of the autoclaved sand-lime brick is moisture content, thus the following study on the impact of moisture content on shear strength of masonry.

When laying the autoclaved sand-lime brick, the internal moisture distribution is not always evenly distributed, the following three cases may happen:(1) after watering, masonry surface moisture content greater than the internal;(2) drying inadequate block surface moisture content less than the internal; (3) surface moisture and the internal moisture content remained the same. Based on the above three cases, divide the test pieces into $\mathrm{A}, \mathrm{B}, \mathrm{C}$ three categories, each category according to the size of the moisture content was divided the test pieces into $4 \%, 6 \%, 8 \%, 10 \%, 12 \%$ $14 \% 16 \%$. Before the test, three specimens previously soaked in water after 24 trials, Class A specimen is placed in the outdoor air-dried to a moisture content of less than $2 \%$, the surface of the water spray $2 \mathrm{~h}$ and then air-dried to a moisture content of the set, in which case masonry surface moisture content greater than the internal; class B slow drying specimens at different relative humidity, make the moisture content into the moisture content of set, moisture evenly distributed in autoclaved sand-lime brick; $\mathrm{C}$ class make the pieces dry to moisture content of set in an environment with $50 \%$ relative humidity for use, in which case the block surface moisture content less than the internal. Each shear specimens were measured the moisture content and surface 10mm thick moisture when laying. Autoclaved sand-lime brick measured moisture content, surface 10mm thick average moisture content and the shear strength of the masonry as shown below.

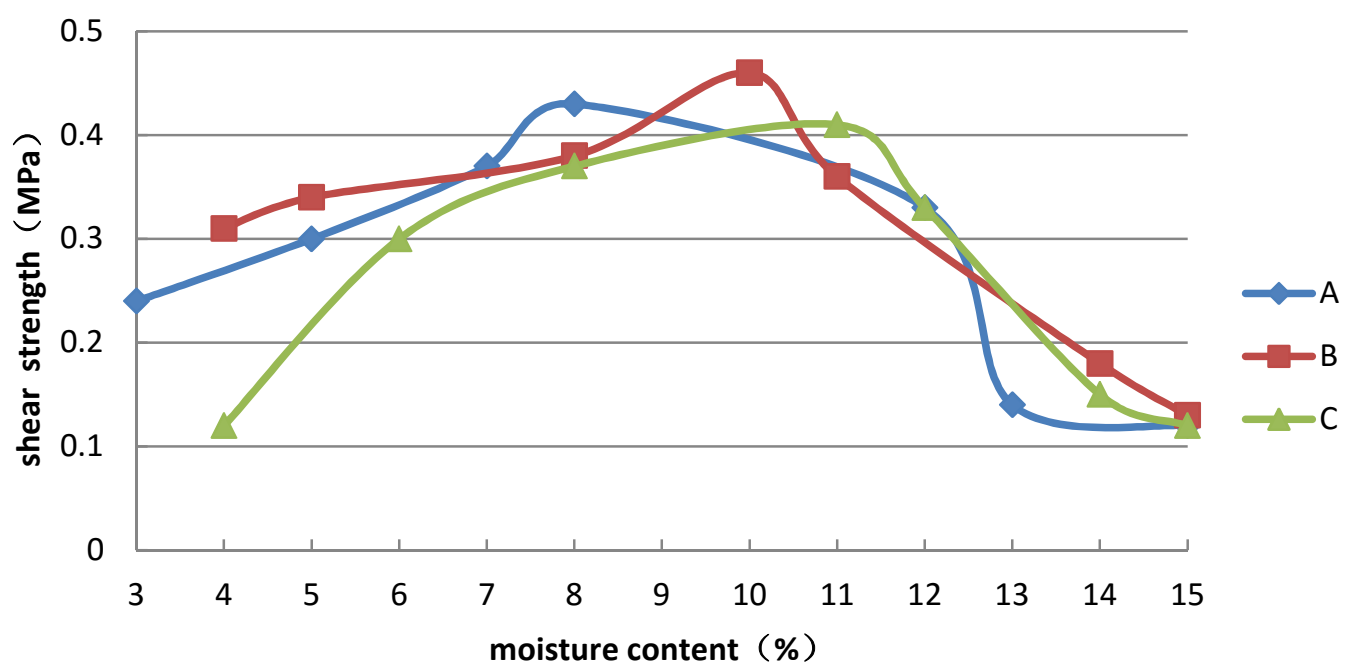

Fig. 2 Effects of the moisture content on the shear strength of autoclaved sand-lime brick. 


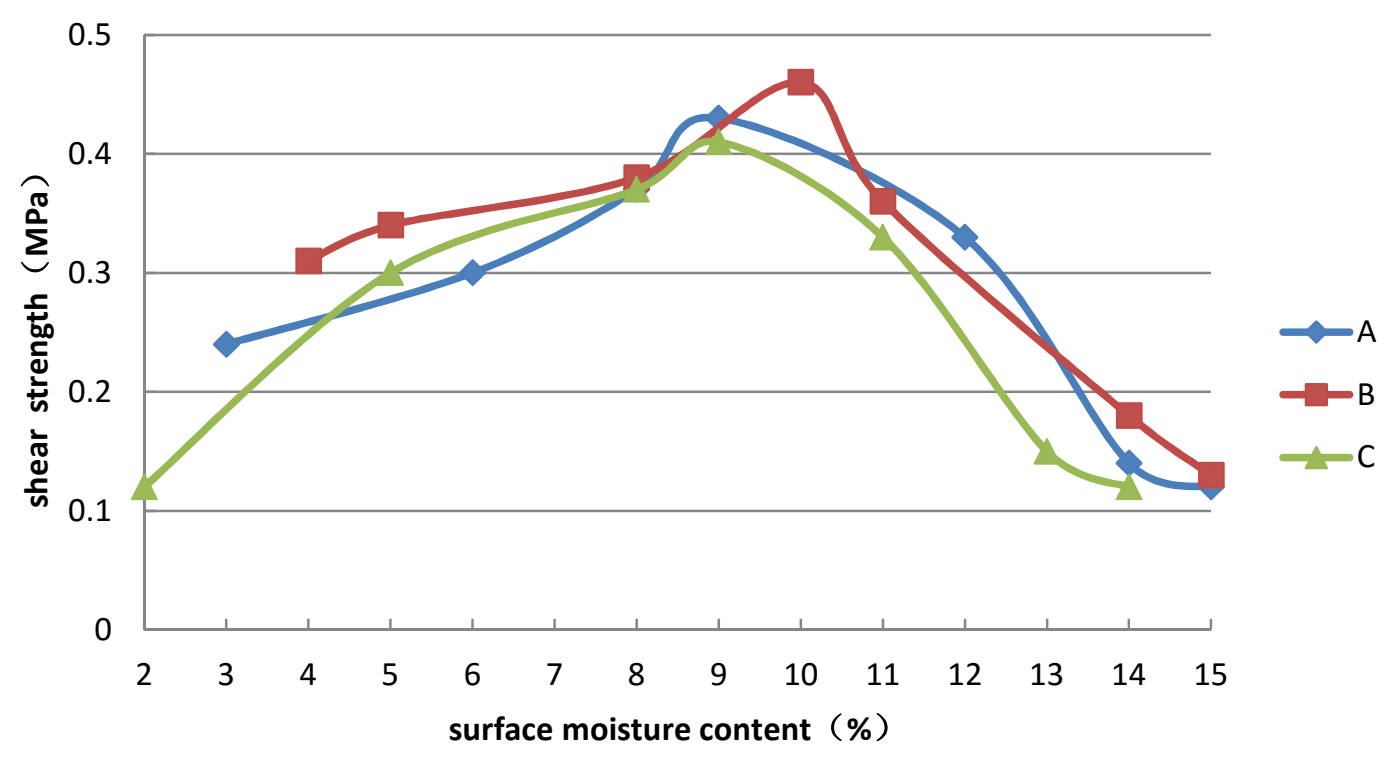

Fig. 3 Effects of the surface moisture content on the shear strength of autoclaved sand-lime brick.

From Figs. 2 and 3 can be found, either the whole moisture or the surface moisture content, there had the optimum moisture content which influence the shear strength on the A, B, C three types autoclaved sand-lime brick. And the optimum moisture content of each type is $8.8 \%, 10.3 \%, 10.8 \%$, the optimum surface moisture content of each type is $9.7 \%, 10.3 \%, 9.1 \%$, the shear strength of the masonry achieved the highest value at the moment. Through the above data analysis, according to the different distribution situations of moisture content, the scope of the optimum moisture content is from $8.8 \%$ to $10.8 \%$, while the range for the surface moisture content is only $9.1 \%$ to $10.3 \%$. Therefore, the optimum surface moisture content is the main factor which influences the shear strength of the autoclaved sand-lime brick, the internal moisture content is the secondary factor.

\section{The Key Construction Technology of Autoclaved Sand-Lime Brick Masonry}

Construction methods of autoclaved sand-lime brick and traditional clay brick are basically the same, but due to production of raw materials and production processes or other factors, if use the traditional construction ways will cause cracks and other problems. Based on the above findings, according to the characteristics of autoclaved sand-lime brick, establish construction technology system of autoclaved sand-lime brick masonry [4].

\section{Process Flow.}

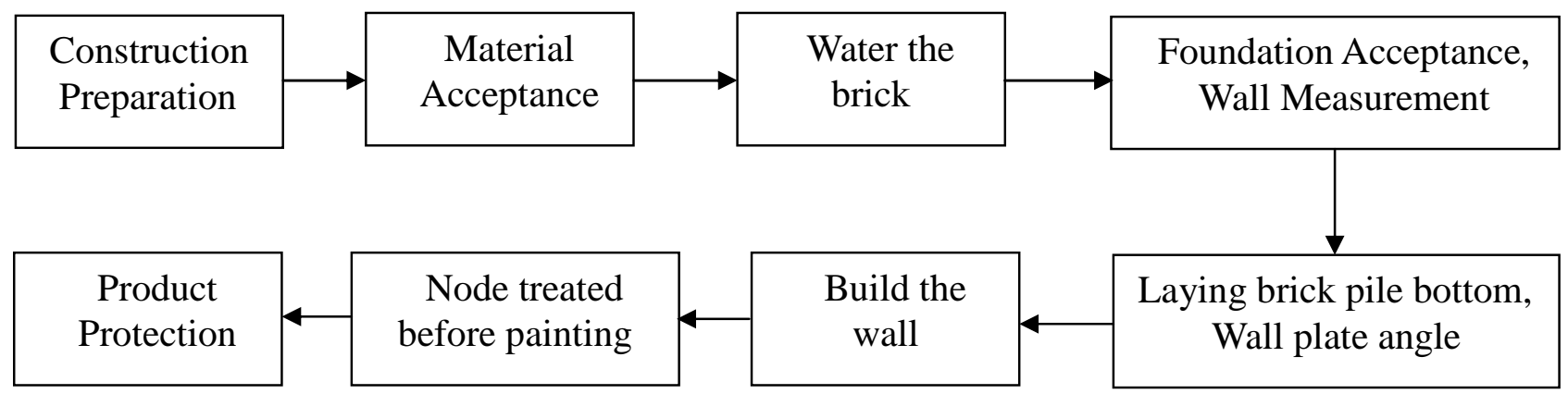

Fig. 4 The construction process of autoclaved sand-lime brick.

Material Requirements. (1) For the missing edge off angle, warping and other relevant indicators that don't reach the standard of autoclaved lime sand brick, shall not be used in the project. 
(2) In the frost area, below ground or moisture levels should not be used with autoclaved sand-lime brick. If must be used, antifreezing measures should be prepared.

Construction Preparation. (1) Autoclaved sand-lime brick disposal site should be smooth, drainage measures and storm(snow) measures should be taken in the surrounding and the top.

(2) Autoclaved sand-lime brick stacking height should not exceed $2 \mathrm{~m}$, and there should maintain an appropriate channel between the stacks.

(3) The autoclaved sand-lime brick should be watered in front 1 2 days of using, the moisture content should be controlled at $10 \%$.

Joint Requirements. (1) Blind sew and sew transparent can affect the quality of autoclaved lime sand brick building seriously, there can not appear in the masonry process.

(2) According to the net area, the horizontal mortar plumpness of masonry shall not be less than $80 \%$, the vertical mortar plumpness of masonry shall not be less than $70 \%$.

Masonry Requirements. (1) The corner of exterior wall or the positioned block shall be the beginning of masonry.

(2) In the process of masonry, the bricks which less than the modulus should not be cut.

(3) The construction method of horizontal mortar seam should be in accordance with the "three one"(a shovel ash, a brick, a squeeze kneading).

Constructional Measures. (1) In-situ reinforced concrete construction column and the top pressure should be added in the parapet, balcony railings and masonry under the long window sills, the spacing of the structural column should not more than $4 \mathrm{~m}$, it should be inserted into the top of the pressure and poured together with the reinforced concrete capping.

(2) The concrete constructional column should be reinforced in a central wall When the wall length is greater than $5 \mathrm{M}$, when the wall thickness and height above the $180 \mathrm{~mm}$ and over $4 \mathrm{~m}$, or the wall thickness is $120 \mathrm{~mm}$ and the height of the wall is greater than $3 \mathrm{M}$, along building height $1.5 \mathrm{M}$ set waist beam or reinforced brick and steel anchor into beams, columns or column.

\section{Conclusions}

According to the survey data, Yi county has rich reserves of gravel, can provide wealth raw materials for wall materials. As the new materials, autoclaved sand-lime brick masonry can instead the traditional baked clay brick, and has good environmental, economic and social benefits. But autoclaved sand-lime brick still has some problems in practical application, need to through tests seeking methods to improve the performance in the future, and improve the construction technology of autoclaved sand-lime brick constantly, promote the rapid development of new building materials.

\section{References}

[1] D. S. Song, Promoting new wall material industry of energy conservation and emission reduction strategies and recommendations, Wall Mater. Innovat. Energ. Sav. Build. 10 (2014) 46-49.

[2] Y. Y. Xie, L. X. Niu, Analysis on construction technology of autoclaved sand-lime brick, Market Forum, 4 (2010) 91-92.

[3] W. Tan, The experimental study on the Autoclaved sand-lime brick masonry to improve the mechanical properties quality (Doctoral dissertation), Changsha University of Science \& Technology, (2014).

[4] L. Zhu, S. Wu, Quality control of autoclaved sand-lime brick in the construction, Tech. Trend. 3 (2010). 